\title{
MAMMALS AND BIRDS AS AGRICULTURAL PESTS: A GLOBAL SITUATION
}

\section{S.M. GOVORUSHKO}

Pacific Geographical Institute, Russian Academy of Sciences, 7, ul. Radio, Vladivostok, 690041 Russia Far Eastern Federal University, 25, ul. Oktyabrskaya, Vladivostok, 690070 Russia, e-mail sgovor@tig.dvo.ru Received February 11, 2014

\section{Abstract}

On the globe there are approximately 7 thousand species of pests injuring agricultural crops. Because of pests' activity from $33 \%$ (D. Geinrikh et al., 2003) to $40 \%$ (D. Pimentel et al., 1999) of world agricultural products are lost with annual financial losses estimated at \$244 billion (D. Pimentel et al., 1997). In spite of the fact that the consequences of plant diseases and harmful insects for plant growing and forage production are discussed more often, economic loss caused by mammals and birds, is quite significant. It surpasses substantially losses put by nematodes, mites and molluscs, though far less than caused by harmful insects. As a whole it is to be noted that size of damage from mammals and birds as agricultural pests decreases gradually, remaining, however, still high. The reason of it consist both in application of modern scientific-design development (new technologies of harvesting, methods of pest control, etc.) and decreasing of populations size of wild animals due to reduction of their area and deterioration of the conditions of the habitat. As a preferred group of animals - agricultural pests, rodents were chosen. Their impact on condition of such branches, as production of grain, forage grasses and ensilage crops as well as vegetable growing, orcharding, and melon-growing is described. In California the annual economic loss from Spermophilus beecheyi at grain production is \$ 8-12 million (S.A. Shwiff et al., 2009). Methods of struggle with rodents are presented. Other types of mammals, the most significant from the standpoint of their injuriousness are described. Information on their composition in a series of world regions is presented. For instance, they are deer, raccoons, and coyotes in the USA, and wild boar, bear and some ungulates in forest temperate zone. The figures of financial loss from them in some countries are given. Impact of plant-eating and omnivorous species of birds on grain-growing, gardening, vegetable growing, seed farming, and breeding of new cultures of plants is considered. In Australia more than 60 avian species are the pests of garden plantings, which cause the annual material loss of $\$ 300$ million (Yu.M. Markin, 2008). The species of birds the most harmful on a global scale are listed, the figures of economic losses from them for a series of countries are presented.

Keywords: rodents, pests, economic loss, damage control measures, globe, agriculture, mammals, birds.

A global influence of nature on people activities as well as anthropogenic

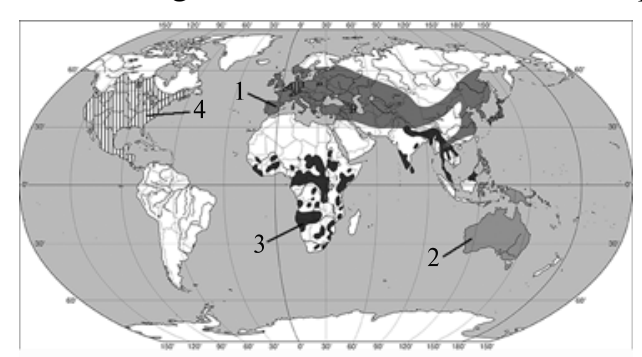
impact on environment are surveyed according to the program for the study of human interaction with the environment (1). Pests are a biotic factor which largely determines the effectiveness of providing mankind with food. The issue is very important because of the extent of the damage caused. In the world the losses from $33 \%$ (2) to

Fig. 1. Global distribution of some mammals and birds damaging agricultural crops: 1 - rooks, 2 - cockatoo, 3 - elephants, 4 - raccoons $40 \%$ (3) and their annual estimation (http://commons.wikimedia.org; http://www.waza.org).

at $\$ 244$ billion (4) were reported.

On the globe there are approximately 7 thousand species of pests damaging agricultural crops (4), the distribution of four of them is illustrated by Fig. 1. Most of them are insects (Insecta). A number of harmful pests are mites from Arachnida class related to insects. Some pests are described among $\mathrm{Mol}$ - 
lusca: Gastropoda and Vermes: Nematoda). discussed.

In this article the role of mammals and birds as agricultural pests are

Rodents. General characteristics. This is the most damaging pests among mammals. Basically they are small animals ranged in weight from one or two dozen to a few hundred grams. Rodents are mainly herbivorous, but in the diet of many species there are also insects, larvae of invertebrates, small reptiles, etc. Rodents differ according to the plant foods they consume. Many species feed on the green parts of plants, which also serve as a source of water. Other rodents require a high-calorie food, and seeds are their preferable diet. In the absence of the necessary feed rodents easy enough change the energy source, for instant they can eat the bark of trees in winter (5).

Extremely high fecundity is a characteristic feature of rodents. The number of small rodents (mice, voles), giving birth to 3-12 cubs up to 5 times a year, can in some years grow 100 times or more (6).

In Russia the rodents damaging the field crops and trees are from $\mathrm{Sci}$ uromorpha, Glirimorpha and Myomorpha groups. Among Sciuromorpha some species such as Pteromys volans L., several species of marmots and ground squirrels, Castor fiber L. and C. canadensis are considered the potential pests. In Glirimorpha the Eliomys quercinus L., Glis glis L., etc., are potentially harmful. The harmfulness of these pests is mainly not high because of their low number.

With regard to pest species number and their harmfulness the Myomorpha group is the most important. Spalax microphthalmus Güld., Cricetus cricetus L., Arvicola terrestris, Clethrionomys glareolus Schr., Microtus arvalis Pall., M. levis and M. socialis are the pests from this group.

Rodents mainly damage grains, vegetables and fruits. Herbivorous forms additionally harm grazing livestock. The harmful effect of rodents is primarily due to their diet

The impact of rodents on crops. On grain crops the harm caused by rodents is quite diverse. Rodents can dig up the sown grain, devour seedlings, gnaw stems, cut and eat the ears, etc. The crop losses vary greatly depending on the pests. In the years favorable for their reproduction the consequences are disastrous. For example, in 1914 in Ukraine voles destroyed $80 \%$ of all crops of rye and wheat. In Czechoslovakia in 1950 the damage of winter wheat, rye and barley crops was estimated at 22.3-68.7 \%, 19.1-71.6\% and 8.5-15.0 \%, respectively. However, even in the years when their number is not above an average score the damage they cause can be quite significant. Thus, in Rostov Province in 1977 the wheat yield was 2.8 or $1.8 \mathrm{t}$ /ha in cases the defense measures against voles were or were not applied (5).

In Indonesia rodents are the main pests on rice crops decreasing the yield by $15 \%$ and more. In Tanzania rodents consume 5 to $15 \%$ of the corn crop (7). In the south-eastern Australia house mouse (Mus domesticus) in some years reduces the wheat yield by 3-4 \% (8). The annual damage to grain production in California only by California ground squirrel (Spermophilus beecheyi) amounts from $\$ 8$ to 12 million (9).

In XX century the losses were mostly related to knitting sheaves at harvesting. Nowadays, in the regions with simultaneous ear maturation the direct harvesting is applied excluding storage of sloping plants in the field and thus significantly reducing the damage caused by rodents. Nevertheless, in case of harvesting by separate combining, when plants are mowed and then dried to ripeness in rolls, the damage from rodents remains significant.

During the development of virgin lands, where the combination of virgin and cultivated territories creates the optimal living conditions for Citellus, the 
damage caused by them was huge. For example, in 1957 in Alma-Ata region gophers completely destroyed 900 ha of winter wheat crops (5). The greatest damage was typical for a field edge of 50-100 m, where up to 60-80 animals per 1 ha were often caught. Nevertheless, their number was managed and the grain loss minimized.

So far as gophers can cause damage throughout the plant development cycle from seedling emergence to heading, their harmfulness is high. Another important trait is their voracity, as one animal is able to eat up to $22.5 \mathrm{~kg}$ of wheat for the season (10). Thus, during the development of virgin lands the losses could amount $1.8 \mathrm{t} / \mathrm{ha}$. Currently, however, due to a sharp decline in the number of gophers they have no economic value. Some destruction of cereal crops is also caused by jerboa, damaging mainly the shoots of maize and wheat, and by hamsters.

Rodent-related damage to vegetable and melon crops. In general, such feeding behavior is less characteristic to rodents and these plants are extra components in their diet. However, the damage is rather clear. Wood mouse damages vegetables and melons on the distance up to $2 \mathrm{~km}$ from the woods. It gnaws the flesh and eats away seeds from watermelon, melon, cucumber, tomato. Field mouse damages the root-crops and zucchini.

All melons are damaged by gophers. Jerboa digs the sowings and eats the germinating seeds of watermelon, melon, cucumber and sunflower. Mole rats and Ellobius, constantly dwelling belowground, may mainly harm the root-crops. Hamsters and Myospalax psilurus Milne-Edwards commonly eat various root vegetables such as beets, turnips, carrots, etc. Field mouse, common hamster, Manchurian Zokor, water voles and great mole rat eat potato leading to yield loss. Vegetable and melon crops are also much harmed by Nesokia indica Gray (11).

In Rajasthan (India) the losses of vegetables from the rodents vary from 4.1 to $19.9 \%$ depending on the crop and are of $8.7 \%$ on average. The major pests are Mus booduqa Gray and Gerbillus gleadowi, at that the tomatoes and eggplants are most harmed (12).

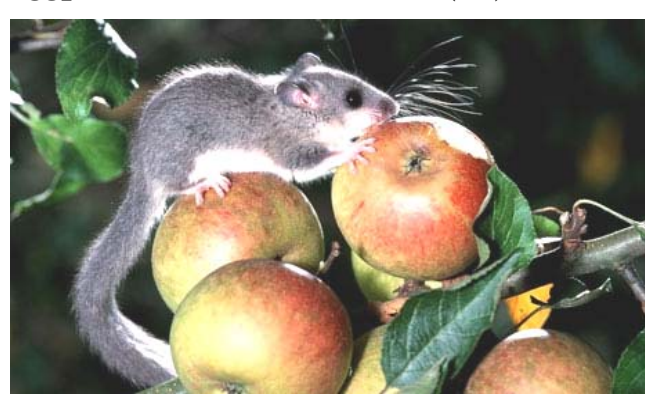

Impact on fruit crops. Rodents eat seeds and fruits, dug seedling from the soil, gnaw the bark and thin twigs. Feeding specialization among rodents differs. Loirs damage nut crops, as well as stone fruits, gnawing out pits and eating flesh of apple (Fig. 2), peaches and apricots, and also grape is often damaged. Forest dormouse eats and damages apples and pears. Voles gnaw

Fig. 2. Loir eats the apple (Great Britain). The animal eats walnuts, chestnuts, berries, fruits such as pears, apples, grapes, cherries, plum, mulberry. In the Northern Caucasus during summer each loir consumes 400 pears. Steven Morris photos, September, 2010. the bark and roots, hares gnaw the bark and lower branches in winter, eat the young shoots, and mole rats and Ellobius gnaw roots of fruit and berry crops, causing their weakness.

The fruit yield losses from rodents can be rather significant. In Germany when the number of Microtus arvalis increased, the losses of apple trees production were estimated at $€ 25$ million per year (13). In the East USA the Microtus pennsylvanicus and $M$. pinetorum, gnawing the bark, damage $5.6 \%$ apple trees, being equal to annual losses from $\$ 40$ million (14) to $\$ 50$ million (15). In hazelnut plantations of Cuneo, Italy, the number of Glis glis ranges from 4.13 to 247 individuals per $1 \mathrm{ha}$, and in the areas of the highest concentration they consume up to $61 \%$ of the hazelnut crop (16). 
Impact on other crops. Their list is not limited to grain, vegetable and fruit crops. The Meriones erythrourus Gray significantly damage cotton plants, crunching boxes and husking seeds. Field and wood mouse, as well as gophers actively damage the sunflower crops. Thus, Citellus pygmaeus Pall. gnaw off the upper part of seedlings what makes a young plant to produce a lot of side shoots, and as a result such plants are removed at weeding.

Many rodents are the pests of sugarcane. They feed both on upper parts of the plant and on its roots. They also damage the roots when digging holes, causing plant lodging in the wind. In addition, microorganisms can get the injured stems, thus reducing the sugar content. In India the major pests of sugar cane are Bandicota bengalensis, Tatera indica and Mus musculus. They cause from 8.6 to $12.1 \%$ losses in sugarcane with $31.5 \%$ decrease in weight and $24.5 \%$ decrease in sugar content (17).

Rodents as pests of pastures. In addition to a significant destruction of green mass, rodents alter the qualitative composition of grasses, eating the most valuable forage species. The Rhombomys opimus Licht. is a harmful pest of pastures in the Central Asia and Southern Kazakhstan. These animals eat prostrate summer-cypress, sedge, wheatgrass, astragalus, and thus are a serious competitor to livestock, especially sheep (5).

The following data can illustrate the rodent-related damage to livestock. Thus, Meriones erythrourus Gray in case its number is within an average limits can eat up to $20-30 \%$ of valuable grasses. At gophers' population density of 30 individuals per $1 \mathrm{ha}$, the yielded green fodder dry weight may be annually reduced by more than $1125 \mathrm{~kg} / \mathrm{ha}$, or by $38 \%$. Vole population density of 250 individuals per 1 ha is capable of destroying up to $4 \%$ of the annual alfalfa harvest. Marmots eat daily up to $0.45 \mathrm{~kg}$ of green fodder, and even more plants they trample when paving their paths. Gophers from North and Central America consume a quarter to a third of the crop of alfalfa (10). In Poland during the outbreaks of common vole Microtus arvalis these animals damage up to $45.8 \%$ of the alfalfa (13). One pika when procuring food can collect plants in haystacks of $20 \mathrm{~kg}$ in weight (18).

Damage from rodents and their control. It is obvious that the global damage from pests like rodents is very significant. According to some estimates, they damage or destroy $1 / 5$ to $1 / 3$ of agricultural products (19), but these figures are obviously overestimated. The damage is basically rat- and mice-associated. In Asia rats eat annually the food enough to feed 200 million people (20). In 10 counties of the State of California (USA) the annual financial losses of crop from rodents and birds range from \$ 168 to 504 million (9).

Technological, mechanical, chemical and biological approaches can be used to prevent losses from rodents.

Technological measures are mostly preventive and restrict animal spreading and reproduction. For instance, in case the yield is completely removed from fields, the rodents in winter are short of food that they need to stay alive and reproduce. Deep plowing which destroys holes and crop rotation also can serve as preventive technologies. Mechanical methods include the extermination of rodents with traps, snares, etc. Poisoned food baits, powdered preparations for dusting burrows and the gaseous toxic substances, mainly used indoors against rats, are the most popular chemical preparations applied. Biomethods include the use of natural enemies of rodents such as cats, dogs, кошек, hedgehogs, ferrets, mongooses and birds of prey, etc.

Othe r mammals. General characteristics. In most agricultural pests the harmfulness is related to plant consumption as a fodder. In mammals the harmfulness is mainly caused by simple moving through and under the plantings. 
The Talpa europaea, when daggering their tunnels, destroy plant roots thus interfere plant nutrition that often results in plant death, also they eat the earthworms valuable for soil fertility. A significant harm is due to crop trampling by large mammals. In general, destroying agricultural plants by wild animals is rather common.

In different regions the list of large animals injuring crops changes significantly. In USA the $53 \%$ of the interviewed farmers indicated Odocoileus spp. being the most harmful, while Procyon lotor and Canis latrans were considered the most problem species by $25 \%$ and $24 \%$ of respondents, respectively (21).

In South China (Yunnan) the major pests are elephants, monkeys, bears, gaurs, deer and wild pigs, at that $90 \%$ losses are due to Elephas maximus (22).

In Africa many animal species cause losses in agriculture. Of them the elephants, baboons, monkeys, hippos, porcupines and bats are the most harmful, and the banana, cocoa, maize, rice and sorghum plantations are most damaged.

In each country the main pests are specific. In some territories of Uganda they are elephants Loxodonta africana which destroy up to $21 \%$ of total yield (23), and in Entebbe suburb green monkeys Cercopithecus aethiops mostly harm the fruit plantations (24). In Zambia Potamochoerus porcus, Loxodonta africana, Papio ursinus, Cercopithecus aethiops) Hippopotamus amphibius and Hystrix cristata are the main harmful mammalians (25).

In the forest area of the temperate zone the problem species are wild boar, bear, and some ungulates. Thus, bears damage the oat fields that they visit as the grain begins to fill, but especially strong impact occurs at the phase of wax ripeness (26). In the remote areas of the Leningrad and Vologda provinces 2-3 bears got into the habit to visit oat crops sometimes completely suck and trample up to 10-15 ha during an autumn season (27). In France crop damage by wild boars and deer in 2007 was estimated at 22-23 million Euros (28).

Sometimes foxes and jackals damage the crops. Finding melon field, they regularly visit it until the end of the harvest, and eat only ripe melons. In some areas these animals consume up to 5-7 \% of the crop (29).

In many parts of the globe the dangerous pests include hares, i.e. Lepus europaeus, L. timidus, L. tolai and L. mandshuricus. Hares eat sunflower, buckwheat, cereals, vegetables and melons, they also can chew the bark of 10-15 apple and pear trees during a night. The most serious problems are caused by hares in Argentina, Australia, and to a lesser extent in North America (30).

Economic damage from wild mammals. Evaluations of economic damage due to them are few, and those reported are not reliable as often based just on the words of the victims. In the United States in 1992 each of the surveyed farmers spent an average of 43.6 hours and 1002 dollar, trying to stop the damage from wildlife or prevent it (18). Throughout the country only in 1989 the wildlife-induced crop damage amounted $\$ 343$ million. The main part of the losses ( $\$ 247$ million) occurred in field crops, $\$ 53$ million lost resulted from the damaged vegetables, fruits and nuts, and another $\$ 16$ million loss was related to other agricultural crops (31).

P.D. Curtis (22) estimates the annual crop losses from wild animals in USA at $\$ 500$ million. The total losses, including livestock husbandry, exceeded $\$ 1$ billion (32). In Xishuangbanna of Yunnan, China, in 1994 the losses from wild animals in agriculture reached 4 million yuans, being equal to about $\$ 482$ thousand (22).

Indian elephant as a harmful species. These animals are the most harmful pests among mammals. About $20 \%$ of the world's population presently lives in the elephants' area or near the places of their habitat. In most areas where the elephants are spread they greatly harm the crops, mainly rice, corn, bananas and 
green peppers (22).

Just trampling can cause significant losses. In Salakpra of Thailand in 2006 there were registered 462 invasions of elephants to farmers' fields (33). Elephants also mark trees and bushes, and sometimes they knocked them to demonstrate or test the power or for emotional release.

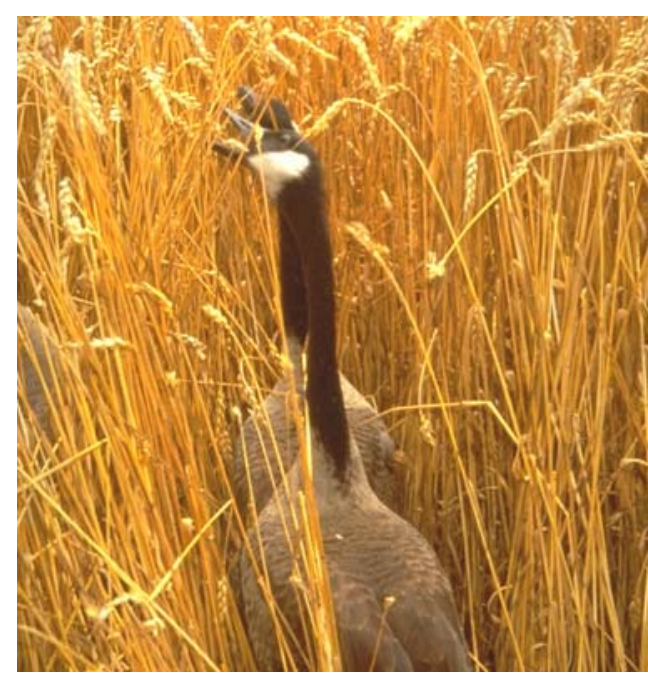

Fig. 3. Canadian geese on a wheat field in Colorado (USA). They are not priority pests, but eat both young seedlings and grain (http://lib.colostate.edu/research/agnic/crops.html).
Very big losses, an average 1,121 billion $\mathrm{Rs}$, or $\$ 11,928$ million are due to elephants in Sri Lanka (34). The plantations are most attacked in the southern regions, where an average loss during vegetation is 12049 Rs per each farmer, or $\$ 128$, that is about a third of earn. Besides, most farmers, up to $70 \%$, should spend significant money to protect their yield. Some of them cultivate less valuable crops, such as sweet potato and cassava, at the edges of fields to reduce the damage of valuable crops, and some use unfixed dates for seeding and harvesting in the view not to lose the whole yield at an overnight raid of elephants. Another way to protect crops is using plants rejected by elephants. In the areas of the most violent conflict the peasants simply leave the arable land because the tries to grow crops are obviously senseless (35).

Birds as pests. This problem is known for a very long time. The study of frescoes and paintings on ancient Greek and Egyptian vases shows that even then man suffered from an attack of birds on vineyards and orchards. The main damage from birds is due to their food-getting activity, which leads to losses of agricultural and raw materials at all stages of growth, primary processing, storage, transportation and industrial use. Herbivorous and omnivorous birds cause damage to grain (Fig. 3), fruit, vegetables, and seed production, and also to plant breeding (36).

The use of those or other plants is determined by taxonomic position and the ability to find suitable feed. Thus, the Fringillidae birds such as finches, siskins, goldfinches, crossbills, etc., and Ploceidae, namely sparrows, fanciscanus, etc., cause the extensive damage to agriculture in the southern regions of the European Russia, Ukraine, Moldova, Kazakhstan and in the Central Asia, eating seeds of sunflower, cannabis, millet, and wheat (10).

In Krasnodar Krai the rooks and other corvids, starting with the spring time, hatch out of the ground the just sown seeds of sunflower, soybeans, and later damage their seedlings by pulling young plants or biting their appeared cotyledons (37). In the state of North Dakota (USA) the sunflower and corn crop losses from birds were 1.2-3.0 \% (38).

A threat from some species can be great. Thus, the population of Quelea quelea from Africa is the biggest. These birds form migrating colonies, each being up to 30 million individuals in number. They eat sorghum, wheat, barley, rice, sunflower and maize. A colony of 2 million individuals can consume 50 tons of grain per day, for which they are sometimes called feathered locust (39). In Scotland up to $25 \%$ of oat and $20 \%$ of barley are eaten by rooks. In USA an average grain losses from Agelaius phoeniceus is $16.2 \%$ (40). Annual grain 
losses of 60 ton from Grus grus L. are reported by Yu.M. Markin in the European Russia (41).

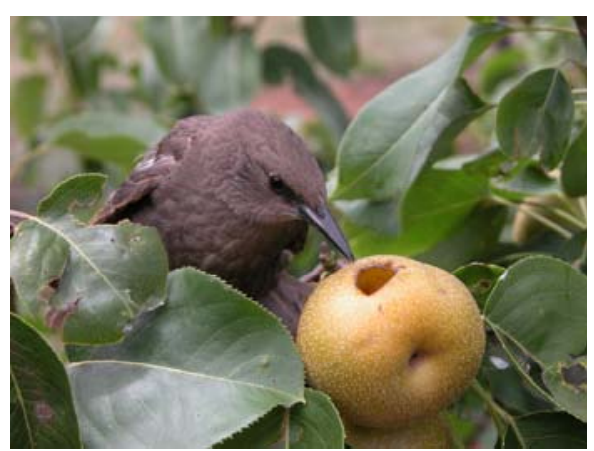

Fig. 4. Young starling pecks pear (New South Wales, Australia). Starlings are among the most harmful birds, they are most dangerous for gardening (eat grapes, cherry, plums, cherries, apricots, apples, etc.). Photo: B. Lukins. January 30, 2004. pies, and fieldfare peck different kinds of berries, the damage to strawberry is particularly widespread. In central Russia pecking soft apples is typical.

In Ferrara province, the Northern Italia, pheasant is most economically important pest bird, damaging crops and vegetables. Starlings and sparrows cause significant damage to fruit and grapes. Magpies damage melons, watermelons and melons. Wild pigeons and ducks consume forage grasses (44).

Economic losses caused by birds on crops. Damage from birds is quite large. For example, in Australia the annual losses only in gardening are $\$ 300$ billion (42). In this country there are more than 60 species of birds, damaging horticultural crops (Fig. 4). In Africa, the damage to crops only from Quelea quelea is \$ 70 million per year (39), including \$ 6.3 million in Sudan and about \$ 1 million in Somalia (45). The annual cost of the vineyard invasions of common and pink starlings only in Tunisia amounts 8-10 million DM (42).

Over time the species composition of bird pests can vary, sometimes dramatically. For example, in Germany in the late 1970s the greatest damage was due to starlings (10 million DM), blackbird (2.4 million DM), wood pigeon ( 2 million DM), and rook (0.1 million DM). In the early 1990s wild wintering ducks and geese (42 million DM), wood pigeon (1 million DM) and corvids such as crows, jackdaws, rooks, magpies, etc. (0.5 million DM) became the most dangerous (46).

In conclusion it should be emphasized that the financial damage from mammals and birds is still very significant. For example, in the United States in 2001 it amounted to $\$ 619$ million for field crops and \$ 146 million for the fruit and nut crops (47).

Thus, despite the consequences of the diseases and invasion of insects for crop and forage production are commonly discussed, the damage from mammals and birds is much greater than, for example, the losses inflicted by nematodes, mites and slugs, although much less than those caused by insect pests. In general, the damage caused by mammals and birds as agricultural pests is gradually reduced, however, remaining still high. The reasons lie in the application of modern scientific and engineering developments such as new harvest technology, the measures for plant protection, etc., and also in reduction of wildlife populations due to the limitations of their natural habitat and deterioration of environmental conditions. Among the animals the rodents still are a priority group of 
agricultural pests, but significant damage is caused by other species. Their sets vary depending on the specificity of regional conditions and cultivated crops.

\section{REFERENCES}

1. Govorushko S.M. Vliyanie geologicheskikh, geomorfologicheskikh, meteorologicheskikh $i$ gidrologicheskikh protsessov na chelovecheskuyu deyatel'nost'. Illyustrirovannoe spravochnoe posobie [Influence of geological, geomorphologic, meteorological and hydrological processes on human activity]. Moscow, 2007.

2. G e in rikh D., G e rgt M. Ekologiya: dtv-Atlas [Ecology]. Moscow, 2003.

3. Pimentel D., Bailey O., Kim P., Mullaney E., Calabrese J., Walman L., $\mathrm{N}$ e 1 s o n F., Y a o X. Will limits of the Earth's resources control human numbers? Environ. Dev. Sustain., 1999, 1: 19-39.

4. Pimentel D., Wilson C., McCullum C., Huang R., Dwen P., FlackJ., Tran Q., Salt man T., Cliff B. Economic and environmental benefits of biodiversity. BioScience, 1997, 47(11): 747-755 (doi: 10.2307/1313097).

5. B o ndare n k o N.V., Gu s' k ova L.A., P e ge l'man S.G. Vrednye nematody, kleshchi $i$ gryzuny [Harmful nematodes, acaridae and rodents]. Moscow, 1993.

6. $\mathrm{R}$ a is E.D.L. Prirodnye sredstva zashchity rastenii ot vreditelei [Natural plant protection from pests]. Moscow, 1986.

7. Le irs H. Management of rodents in crops: the Pied Piper and his orchestra. In: Rats, mice and people: rodent biology and management. G.R. Singleton, L.A. Hinds, C.J. Krebs, D.M. Spratt (eds.). Canberra, 2003: 183-190.

8. Stenseth N.C., Leirs H., Skonhoft A., Davis S.A., Pech R.P., Andreassen H.P., S inglet on G.R., Li ma M., M a changu R.M., Makundi R.H., Zhang Z., B row n P.B., Sh i D., W a n X. Mice and rats: the dynamics and bioeconomics of agricultural rodents pests. Front. Ecol. Environ., 2003, 1(7): 1-12.

9. S hw iff S.A., G e bhardt K., K i rkpat $\mathrm{rick}$ K.N. The economic impact of bird and rodent damage to California crops. USDA/APHIS/Wildlife Services, National Wildlife Research Center, 2009.

10. Sokolov V.E., Il'ichev V.D., Emel'yanova I.A. Mlekopitayushchie $i$ ptitsy, povrezhdayushchie tekhniku i sooruzheniya [Mammals and birds damaging equipment and facilities]. Moscow, 1990.

11. Biologiya lesnykh ptits $i$ zverei [Biology of forest birds and animals]. Moscow, 1975.

12. Advani R. Rodent damage to various annual and perennial crops of India and its management. Proc. of Great Plains Wildlife Damage Control Workshop. Lincoln, 1987: 108-112 (http://digitalcommons.unl.edu/cgi/viewcontent.cgi?article=1046\&context=gpwdcwp).

13. J a c ob J., Tkadlec E. Rodent outbreaks in Europe: dynamics and damage. In: Rodent outbreaks: ecology and impacts. G.R. Singleton, S.R. Belmain, P.R. Brown, B. Hardy (eds.). Los Bacos, 2010: 207-224.

14. Tobin M.E., Rich mond M.E. Vole management in fruit orchards. US Fish and Wildlife Service. Biological Report 5. 1993 (http://www.aphis.usda.gov/wildlife_damage/nwrc/publications/93pubs/93-42.pdf).

15. La pasha D.G., Powe 11 R.A. Pine vole (Microtus pinetorum) movement toward areas in apple orchards with reduced populations. J. Hort. Sci., 1994, 69: 1077-1082.

16. Ghirardi M., Tizzani P., Demat te is A. Impact of the fat dormouse (Glis glis Linnaeus 1766) on hazel orchards in the area of Alta Langa and Belbo, Bormida, Uzzone Valleys (province of Cuneo, Italy): a preliminary assessment of agricultural damage. Proc. of $8^{\text {th }}$ European Vertebrate Pest Management Conference. Berlin, 2011: 107-108 (doi: 10.5073/jka.2011.432.057).

17. http://pub.jki.bund.de/index.php/JKA/article/viewFile/1520/1851.

18. Shanthy R., Thiagarajan R., Prathap D.P. Management of rats as pests of sugarcane. Printrite, 2007.

19. Con over M.R. Perceptions of American agricultural producers about wildlife on their farms and ranches. Wilflife Society Bulletin, 1998, 26(3): 597-604.

20. On is h chen k o G. Krysa - ochen' umnoe zhivotnoe [Rat, a very clever animal]. Moscow, 2007. (http://agronews.ru/news/detail/49704/).

21. $\mathrm{S}$ i n g l e t o n G.R. Impacts of rodents on rice production in Asia. Los Bacos, 2003.

22. C u r t i s P.D. Deer damage and control. In: Encyclopedia of Pest Management, 2002.

23. T i s d e 11 C.A., X i a n Z Z. Protected areas, agricultural pests and economic damage: a study of elephants and other pests from Xishuangbanna State Nature Reserve. Brisbaine, 1995.

24. H o r r R.E. Data collection and analysis protocol for human-elephant conflict situations in Africa. Arusha, 1999.

25. S a j T.L., S i c ot te P., P a t t e r s o n J.D. The conflict between vervet monkeys and farmers at the forest edge in Entebbe, Uganda. African Journal of Ecology, 2001, 39(2): 195-199.

26. B a lakrishnan M., $\mathrm{Ndhlovu}$ D.E. Wildlife utilization and local people: a case study in Upper Lupande game management area, Zambia. Environmental Conservation, 1992, 19(2): $135-154$. 
27. P a z h e t $\mathrm{n}$ ov V.S. Buryi medved' [The brown bear]. Moscow, 1990.

28. Makridin V.P., Ve re sh chag in N.K., T a ry a $\mathrm{n} n \mathrm{ik}$ ov V.I. et al. Krupnye khishchniki $i$ kopytnye zveri [Large carnivors and ungulates]. Moscow, 1978.

29. Lamarque F., Anderson J., Fergusson R., Lagrange M., Osei-Owusu Y., $\mathrm{B}$ a k k $\mathrm{r}$ L. Human-wildlife conflict in Africa. Causes, consequences and management strategies. Rome, 2009.

30. Vaughan N., Lucas E., Harris S., White P.C.L. Habitat associations of European hares Lepus europaeus in England and Wales. Implications for farmland management. J. Appl. Ecol., 2003, 40(1): 163-175 (doi: 10.1046/j.1365-2664.2003.00784.x).

31. Conover M.R., Pitt W.C., Kessler K.K., Dubow T.J., S a n bor n W.A. Review of human injures, illnesses and economic losses caused by wildlife in the United States. Wildlife Society Bulletin, 1995, 23(3): 407-414.

32. You de r J. Estimation of wildlife-inflicted property damage and abatement based on compensation program claims data. Land Econ., 2002, 78(1): 45-59 (doi: 10.2307/3146922).

33. Lyudi protiv slonov. National Geographic, 2009, 6: 25.

34. $\mathrm{B}$ a n d a r a R., T is d e 11 C. Wildlife damage, insurance/compensation for farmers and conservation: Sri Lankan elephants as a case. Brisbane, 2004.

35. B a n d a r a R., T i s d e 11 C. Asian elephants as agricultural pests: damages, economics of control and compensation in Sri Lanka. Brisbane, 2002.

36. Govo ru sh k S.M. Natural processes and human impacts: interaction between humanity and the environment. Dordrecht, Springer, 2012.

37. Medvedeva N.V., S e m e re n ko S.A. Materialy VI Mezhdunarodnoi konferentsii molodykh uchenykh $i$ spetsialistov [Proc. VI Int. Conf. of young researchers and experts]. Krasnodar, 2011: 189-194.

38. Linz G.M., Slowik A.A., Penry L.B., Ho man H.J. Bird damage to corn and sunflower in North Dakota. Proc. of 31st National Sunflower Association Research Forum, 2009 (http://www.sunflowernsa.com/research/research-workshop/documents/Linz_etal_BirdDamage_09.pdf).

39. Markula A., Hannan-J ones M., Csurhes S. Pest animal risk assessment: Redbilled quelea Quelea quelea. Brisbane, 2009 (http://www.daff.qld.gov.au/ data/assets/pdf_file/0011/57845/IPA-Red-Billed-Quelea-Risk-Assessment.pdf).

40. I 1 ' i c h $\overline{\mathrm{e}} \mathrm{v}$ V.D. V sbornike: Zashchita materialov $i$ tekhnicheskikh ustroistv ot ptits [In: Protection of equipment and devices from bird damage]. Moscow, 1984: 7-72.

41. M a r k i n Yu.M. Sel'skokhozyaistvennaya Biologiya [Agricultural Biology], 2008, 4: 110-113.

42. Tracey J., Bomford M., Hart Q., Saunders G., S inclair R. Managing bird damage to fruit and other horticultural crops. Canberra, 2007.

43. $\mathrm{Dzhabbarov}$ A. Materialy 12-i konferentsii molodykh uchenykh MGU (Biologicheskii fakul'tet) [Proc. 12 th Conf. of young researchers of the Moscow State University, Biological Department]. Moscow, 1981: 29-32.

44. Pag n o n i G.A. Impatto della fauna selvatica sulle attivita agricole nella provincia di Ferrara. Suppl. ric. boil. selvagg., 1997, 27: 685-691.

45. E 1 i a s D.J. Pests with backbones. Cerescope, 1988, 21: 29-34.

46. G e m m e k H. Art und Umfang von Schagen durch Vogel in der Landwirtschaft heute (Vidy $i$ ob"emy ushcherba ot ptits $v$ sovremennom sel'skom khozyaistve). Mitt. Biol. Bundesanst. Landund Forstwirt. Berlin-Dahlem, 1996, 321: 371.

47. U.S. Wildlife Damage. National Agricultural Statistics Service (NASS). Washington, 2002. 